\title{
自己に対する評価と接近回避志向の関係性 ${ }^{1}$ 制御焦点理論に基づく検討
}

\author{
尾崎 由佳 ${ }^{2}$ 東海大学 唐沢 かおり 東京大学
}

\author{
Valences of self-evaluation and approach-avoidance tendencies: \\ Research based on regulatory focus theory
}

\author{
Yuka Ozaki (Tokai University) and Kaori Karasawa (University of Tokyo)
}

\begin{abstract}
Four studies were conducted to investigate the relationship between valences of self-evaluation and approach-avoidance tendencies. Based on regulatory focus theory (Higgins, 1997, 1998), we predicted that positivity of self-evaluation is related to the tendency to approach gains, while negativity of self-evaluation is related to the tendency to avoid losses. In Study 1, a self-report measure of behavioral tendencies for approaching gains and avoiding losses was developed. In Studies 2 to 4, correlations between these approach/avoidance tendencies and various kinds of self-evaluations were examined. Overall, the authors' predictions were supported. The results suggest that the self-evaluation system and the self-regulation system work in close cooperation with each other in controlling human behavior.
\end{abstract}

Key words: self-regulation, self-evaluation, regulatory focus, approach/avoidance tendency, self-esteem.

The Japanese Journal of Psychology

2011, Vol. 82, No. 5, pp. 450-458

人間は自分自身に対してさまざまな評価を下す。た とえば自らの長所を肯定的に評価することもあれば, 短所に目を向けて否定的に評価することもある。この ような自己評価の仕方の違いは，その人のふるまい方 とどのような関倸性にあるのだろうか。そもそも，な ぜ自己に対する評価が，ふるまい方に影響を与えるの だろう。本研究の目的は, 自己評価が自己制御傾向と どのように関連するのかについて検討することである。

\section{自己評価と接近回避}

心理学における自己制御という用語は，人間が目標 を達成するために自らの判断・感情・行動などをコン トロールする現象およびそれに関連するプロセスのこ とを意味する。自己制御のプロセスにおいて人間はさ まざまな志向性を示すが，その中で本研究が注目する

Correspondence concerning this article should be sent to: Yuka Ozaki, Student Project Center, Tokai University, Kitakaname, Hiratsuka 259-1292, Japan(e-mail: yukaoz@tokai.ac.jp)

本研究は, 松下国際財団研究助成 (05-037) および文部科 学省科学研究費補助金 (若手研究 (B) 21730499) の助成を受けた 研究の一部である。

2 本研究の実施にあたり有泉 優里先生と大高 瑞郁先生にご 協力いただきました。心より感謝申し上げます。
のは接近志向と回避志向の違いである。従来の自己制 御研究に㧍いて, 接近志向とは望ましい基準に近づこ うとする志向性，回避志向とは望ましくない基準から 遠ざかろうとする志向性と定義されてきた（Carver \& Scheier, 1982)。接近・回避志向と自己評価の関係性 については多数の先行研究があり, その中でも特に自 己高揚・自己防衛と自尊心の関連に関する研究蓄積が 充実している (Baumeister, Tice, \& Hutton, 1989; Tice \& Masicampo, 2008)。この研究文脈では, 高自尊心者 は自己高揚（すなわち自己を肯定的に捉えることに対 する接近志向）を示しやすく, 低自尊心者は自己防衛 （すなわち自己を否定的に捉えることに対する回避志 向）を示しやすいという指摘が多々見受けられる。た とえば Baumeister et al.（1989）によると，高自尊心 者の自己呈示スタイルは “成功のためならばリスクを 進んで受け入れる”“他者よりも秀でている能力を強 調する”など自分の印象を肯定化させようとする接近 志向的な特徴がある。一方, 低自尊心者の自己呈示入 タイルは“失敗しないように慎重にリスクを避ける” “他者よりも能力が劣ることを隠そうとする”など否 定的な印象を持たれる危険性を減らそうとする回避志 向的な特徴があるという。

しかし，この問題については必ずしも研究結果が一 
貫していない。癌患者のコーピング行動の研究 (Roesch, Adams, Hines, Palmores, Vyas, Tran, Pekin, \& Vaughn, 2005）では，“楽観的な期待を持つ”“情報探 索をする”などの接近志向を示す人は自尊心が高かっ たものの，“病を否定する”“無気力になる”などの回 避志向と自尊心の間には関連が見られなかった。ま た, 援助要請研究においては, 援助要請に対して回避 的なのは高自尊心者だという主張（Nadler, 1987）と, 低自尊心者だという主張（Tessler \& Schwartz, 1972） の対立が見られる。

なぜこのような知見の不一致が生じるのだろうか。 可能性の一つとして, 従来の研究で用いられていた接 近志向や回避志向の概念定義（Carver \& Scheier, 1982）の問題が原因となり, 要因間の関係性を不明瞭 にしていることが考えられる。この定義的問題の具体 的な内容については後述する。このような問題を解消 し，自己評価と自己制御の関係性を明確にするために は, 現状の定義に対して再考を加え, 接近志向と回避 志向について新たな枠組みから捉えなおすことが必要 だと本研究では考えた。そこで, 接近と回避について 従来と異なる理論的枠組みを主張した制御焦点理論に 着目した。

\section{制御焦点理論と接近・回避}

快に接近し不快を回避するという快楽原則は, 従来 の自己制御研究において基本原理とされてきた。これ に対して Higgins（1997，1998）は制御焦点理論 (regulatory focus theory) を提唱し，どのようにして 快に接近し不快を回避するのかという快楽原則の追求 のしかたにおいて質的に異なる二種類のモードを区別 すべきであると主張した。制御焦点理論は，快・不快 という二分法だけではなく，それぞれの質的内容を考 慮すべきだと主張した点が特徵的である。接近対象と なる快の状態は, 利得の存在 (gain) と損失の不在 (non-loss) という二種類に分けられる。同様に, 回 避対象となる不快の状態は, 利得の不在 (non-gain) と損失の存在（loss）に分けられる。そして, これら の質的に異なる快・不快の状態に対する接近と回避 は，それぞれが促進焦点 (promotion focus) と予防 焦点（prevention focus）と呼ばれる独立した自己制 御システムによって司られているという。促進焦点は 利得に焦点化した自己制御傾向を示し, 利得の存在に 接近し, 利得の不在を回避するように行動をコントロ ールする。対人関係における自己制御を例にとると,

他者と親しくなることを求め, 親しくなれないことを 避けようとする。一方, 予防焦点は損失に焦点化した 自己制御傾向を示し, 損失の不在に接近し, 損失の存 在を回避するように行動をコントロールする。たとえ ば，他者に嫌われないことを求め，嫌われてしまうこ とを避けようとする。本研究では，促進焦点時に示さ
れる志向性を “利得接近志向”，予防焦点時に示され る志向性を “損失回避志向” と命名し, 以下のように 定義づける。利得接近志向とは, 利得の存在に接近し 不在を回避する自己制御傾向である。一方，損失回避 志向とは，損失の不在に接近し存在を回避する自己制 御傾向である。

ここで, この制御焦点理論の枠組みを用いて, 前述 した自尊心と接近志向・回避志向に関する先行研究の 再解釈を試みる。Baumeister et al.（1989）は接近志 向と高自尊心, 回避志向と低自尊心の関連を指摘して いる。ただし, Baumeister らのいう接近志向とは“成 功のためならリスクを進んで受け入れる”など利得の 存在に対する接近，すなわち利得接近志向を意味して いる。一方, 回避志向とは“他者よりも能力が劣ること を隠そうとする”など損失の存在に対する回避, すな わち損失回避志向を意味している。つまり Baumeister らの知見は, 利得接近志向が高自尊心と関連し, 損失 回避志向が低自尊心と関連することを示唆していると 解釈できる。Nadler（1987）は低自尊心者が援助要請 に対して接近的であったと報告しているが，ここでい う接近とは“苦境を脱するための援助を積極的に求め ること”すなわち損失の不在に対する接近であり，損 失回避志向と分類できる。したがって, この研究結果 は低自尊心者が損失回避志向を示しやすいことを意味 すると解釈できる。また Roesch et al. (2005) による 癌患者のコーピング研究では, 自尊心が高いほど接近 志向を示しやすいという関連が示されたが, 回避志向 とは関連が見られなかったという。この研究で接近志 向と分類された反応は “情報探索をする”など利得の 存在に対する接近であり，すなわち利得接近志向を意 味する。したがって, 利得接近志向と高自尊心の関連 が示されたと解釈できる。一方, 回避志向の分類の中 には“病を否定する”など損失の存在に対する回避 （損失回避志向）と“無気力になる”など利得の不在 に対する回避（利得接近志向)3が混在している。この ように概念的な混在が原因となって, 自尊心との関連 が見られなかったのではないかと解釈できる。

上記のとおり，結果が一貫していないように見受け られた先行研究について制御焦点理論による再解釈を 試みたところ, 一貫した結果として解釈可能になっ た。すなわち, 利得接近志向は高自尊心と関連し, 損 失回避志向は低自尊心と関連するという系統的な結果 パターンである。少なくともこれらの研究結果に関し ては, 従来の接近志向 /回避志向という分類法を用い るよりも, 制御焦点理論に基づく利得接近志向 /損失 回避志向という分類法を用いた方が, 自尊心との関連

\footnotetext{
3 制御焦点理論では“無気力になる”という反応について, 利益獲得の見込みが少ないときに達成行動を放棄すること, す なわち利得の不在に対する回避反応と解釈している。
} 
をより明確に整理できたといえよう。ただし，ここで 取り上げた研究例はごく少数であり, かつ既存の研究 に対して後付けの解釈を加えたものであるため, 解釈 の信頼性や妥当性は不明である。この解釈について厳 密な検証を行うためには, 制御焦点理論に基づいて計 画された研究を実施する必要がある。そこで本研究で は, 制御焦点理論を理論的基盤として, 利得接近志 向／損失回避志向という概念を用いた検証を行うこと にした。

\section{自己評価の肯定性 · 否定性}

本研究では, 自己評価に関わる概念に関しても, 制 御焦点理論の枠組みから新たに整理を試みる。自己評 価の肯定性や否定性を扱った先行研究の大半は, 自尊 心という概念を取り上げてきた。自尊心は，大抵の場 合, 高自尊心-低自尊心という一次元構造を持つものと して概念化されている。たとえば，自尊心の代表的な 測定手法であるローゼンバーグ自尊心尺度 (Rosenberg, 1965）は一次元の測定尺度として扱われる。

これに対して, 本研究では自己評価の肯定性と否定 性はそれぞれが独立した次元であり，二次元構造を構 成するという立場をとる。人間は肯定的な評価プロセ スと否定的な評価プロセスを備えており，さまざまな 評価判断や反応生成において各プロセスに対応した二 次元性が見られる（Cacioppo \& Berntson, 1994）。ま た, 本研究が理論的基盤とする制御焦点理論は利得の 存在一不在次元と損失の不在-存在次元を区別すること を重視する。このような理論的枠組みを用いるなら ば，自己評価に扔いても肯定的な属性の存在一不在と 否定的な属性の不在一存在をそれぞれ独立した次元で 扱うべきだろう。そこで本研究では, 自己評価の肯定 性次元と否定性次元を区別する。たとえば“私には長

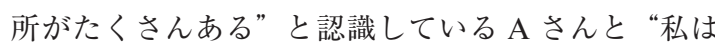
短所がほとんどない”と認識しているBさんがいたと しょう。自尊心という一次元的な概念を用いれば両者 とも高自尊心に分類されるが, 自己評価の二次元性を 想定すれば $\mathrm{A} さ ん は$ 自己評価の肯定性が高い人, $\mathrm{B}$ さ んは自己評価の否定性が低い人として弁別される。

\section{本研究の予測}

上述のとおり自己制御傾向と自己評価について概念 整理をした上で, 本研究では両者の関係性について以 下のような予測を立てる。促進焦点の場合は肯定的な 結果の有無に対して敏感に反応する傾向があるため, 自己評価についても肯定性次元に強く注目するだろ う。そして，もし“私には優れたところがたくさんあ る”というように自己評価の肯定性を高く認識した場 合は, 現在の自分は望ましい状態に向けて順調に近づ きつつあることを意味し, 将来的に高い成果や利益を 獲得できる期待が高まるため, 促進焦点のシステムは
利得接近志向をより強く示すようになるだろう。一 方, “自分には優れたところが何もない”などという ように自己評価の肯定性を低く認識した場合には, そ れは望ましい状態から遠ざかっていくことを意味し， 成果や利益の達成可能性を低く見積もらせるため, 動 機づけを弱めるだろう。したがって, 促進焦点のシス テムは自己評価の肯定性が高いほど利得接近志向を強 め, 逆に肯定性が低いほど利得接近志向を弱めるだろ うという予測が導かれる。ただし，促進焦点の場合に は否定的な属性の有無には注目しないため, 自己評価 の否定性の高低は利得接近志向にほとんど影響しない だろうと考えられる。

一方, 予防焦点の場合は，否定的な結果の有無に対 して敏感に反応する傾向があるため, 自己評価の否定 性次元に強く注目する。もし“自分は欠点ばかりだ などと自己評価の否定性が高くなった場合には, 将来 的な失敗や損害のリスクが高く見積もられるため, 不 安の感情が喚起されて損失回避志向を強く示すように なるだろう。一方, “自分にはあまり欠点がない”な どと自己評価の否定性が低かった場合には，将来的な リスクが低く見積もられ，損失回避に対する動機づけ を弱めるだろう。したがって, 予防焦点のシステム は, 自己評価の否定性が高いほど損失回避志向を強 め, 逆に否定性が低いほど損失回避志向を弱めるだろ うという予測が導かれる。ただし，予防焦点の場合に は肯定的な属性の有無には注目しないため, 自己評価 の肯定性の高低は損失回避志向にほとんど影響しない だろう。

上記の予測について検証するために，本研究では利 得接近志向 - 損失回避志向と自己評価の肯定性 - 否定 性の間の相関関係を調査する。促進焦点のシステムに おいては, 自己評価が肯定的であるほど利得接近志向 が強くなるため，両者の間には正相関が見られるだろ う。ただし自己評価の否定性は利得接近志向の規定因 ではないため, 両者は無相関であろうと考えられる。 一方, 予防焦点のシステムにおいては, 自己評価が否 定的であるほど損失回避志向が強くなるため, 両者の 間には正相関が見られるだろう。一方，自己評価の肯 定性は損失回避志向の規定因ではないため, 両者は無 相関であろうと考えられる。研究 1 においては, 利得 接近志向と損失回避志向を測定する尺度を開発する。 続いてこの尺度を利用し, 自尊心との相関について (研究 2), 性格特性に関する自己評価との相関につい て (研究 3), 自己記述の感情価との相関について （研究 4）を検討する。

\section{研 究 1}

\section{目 的}

研究 1 の目的は, 利得接近志向と損失回避志向を測 
定する尺度を開発することである。制御焦点に関する 尺度は複数存在しているが, 本研究ではそれらの中か ら Promotion/prevention focus scale ${ }^{4}$ (促進予防焦点尺 度：以下 PPFS とする; Lockwood, Jordan, \& Kunda, 2002）を選んだ。なぜなら PPFS は利得接近や損 失回避に対する目標志向性の強さを測定しており (Summerville \& Roese, 2008), 本研究において利得接 近志向と損失回避志向を測定するという目的に合致し ているからである。この尺度は二つの下位尺度から構 成される。一つは，肯定的な結果や成功などといった 利得について頻繁に考えたり，それらを獲得したいと 強く思ったりする傾向を測定する尺度である（利得接 近志向尺度)。もう一つは, 否定的な結果や失敗なと といった損失について頻繁に考えたり，それらを防ぎ たいと強く思ったりする傾向を測定する尺度である (損失回避志向尺度)。研究 1 では, この PPFS を邦訳 して信頼性および妥当性を検討する作業を行った。

\section{方 法}

調査参加者 大学生 233 名 (男 132 名, 女 98 名, 不明 3 名, 平均年齢 $=21.75, S D=4.11 ）$ が参加した。

手続き 英語の原版 18 項目を日本語に翻訳した後, 英語に堪能な研究協力者が再び英語に翻訳し, 原版と の対応を確認した。この翻訳された 18 項目を予備尺 度として調查に用いた。調查は大学の授業時間を利用 して行われた5。予備尺度について, 調査参加者は “1. 全くあてはまらない”から“7．非常にあてはま る”までの 7 件法で評定した。調査参加者の一部（50 名）は, 上記の予備尺度に加えて BIS/ BAS 尺度（安 田・佐藤，2002）にも回答した。

\section{結果と考察}

項目分析 利得接近志向 9 項目について, 合計得点 の中央值（42）を基準に上位群 $(n=114)$ と下位群 $(n=119)$ に分け，上位-下位分析を行った。すべての項 目に扔いて群間の平均值差が有意であった $(t \mathrm{~s}>6.2$, $p<.01)$ 。また，部分一全体相関を算出したところ，す べての項目が合計得点と中程度から強い相関を示した $(r \mathrm{~s}>.49, p<.01)$ 。次に, 損失回避志向 9 項目につい ても同様に合計得点の中央值（39）を基準に上位群 $(n=114)$ と下位群 $(n=119)$ に分け, 上位-下位分析 を行った。すべての項目において群間の平均值差が有 意であった（ $t \mathrm{~s}>2.9, p<.01)$ 。また，部分一全体相関

\footnotetext{
4 原著者には本尺度の邦訳版作成について許諾を得た。

5 調查参加者には, 調查実施前に参加承諾を得るための書面 を配布し署名を依頼することによってインフォームドコンセン 卜を得た。この書面は調査用紙と別に回収して枚数をカウント し, 調查参加者人数抒よび回答済み調查用紙数と合致すること をもって, 全員の承諾を得ていることを確認した。研究 2 から 4 においても同様の手続きを取った。
}

を算出したところ，8項目において中程度から強い相 関 $(r \mathrm{~s}>.52, p<.01)$ が見られたが，相関の弱かった 1 項目（ $r=.28 ）$ は除外した（除外された項目は, 項 目 11 “私は, “自分の義務”を最優先し，自分に与え られた責務や責任を果たそうと努力する夕イプだと思 う。”であった)。

因子分析 残り 17 項目について, 項目の因子構造 を確認するため, 因子分析 (一般化最小 2 乗法・プロ マックス回転）を実施した。第 3 因子以降は固有值の 変化が小さかったため，2因子を抽出した。両因子に 対して因子負荷量の絶対值が.40 以上であった 1 項目 を除外した（除外された項目は，項目 14 “私にとっ ては，失敗を避けることよりも，成功を手に入れるこ との方が大切だ。であった)。最終的に各因子 8 項 目, 計 16 項目が選定され，それぞれを利得接近志向 尺度・損失回避志向尺度と名付けた。信頼性係数はそ れぞれ $\alpha=.80, .75$ であった。利得接近志向尺度と損 失回避志向尺度間に有意な相関は見られず $(r=.09$, $p=.15)$, Lockwood らの原版で報告されている弱い 正相関 $(r=.17, p<.01)$ は再現されなかった。ただ し, 制御焦点理論において各志向はたがいに独立して いると考えられているため, 本研究において両尺度間 に有意な相関が見られなかったことは理論的に矛盾し ないと考えられる。最終的に選定された 16 項目と因 子分析結果の一覧を Table 1 に記す。

妥当性検討 PPFS 邦訳版と BIS/ BAS 尺度との相 関分析を行った 6 。BIS/ BAS 尺度（安田・佐藤, 2002）は，行動抑制システム（behavioral inhibition system：以下 BIS とする）と行動活性化システム (behavioral activation system：以下 BAS とする) と いう二つの独立した自己制御システムを想定して接 近・回避の行動傾向を測るものであり, BAS に関連 する“接近ドライブ”“報酬応答性”“新たな報酬体験 の追求”と, BIS に関連する “懸念・罰感受性” “回 避ドライブ”“抑制性”の計六つの下位尺度を含む。

“接近ドライブ”は欲しいものを手に入れようとす る志向性の強さを表しており, 利得を追求し無利得を 避けようとする利得接近志向と概念的に近似してい る。したがって, 利得接近志向尺度と “接近ドライ ブ”の間に中程度の正相関が示されたことは，この尺 度の構成概念妥当性の高さを表しているといえよう $(r=.48, p<.01)$ 。“報酬応答性”と“新たな報酬体験

6 BIS/ BAS 尺度は, 快・不快それぞれに対する自己制御シス テムを区別していることが特徵である。これに対して PPFS は, 快・不快のみを区別するのではなく，それぞれの中にも質的な 差異があること（たとえば快は“利得の存在”と“損失の不在” に弁別される）を想定している点が異なっている。ただし，い ずれも自己制御における接近と回避を測定する尺度であり, 理 論的関連性が予測されることから, 併存的妥当性の検討方法と してBIS/BAS 尺度の利用が適していると判断した。 
Table 1

PPFS 邦訳版の因子パターン

\begin{tabular}{|c|c|c|}
\hline & 1 & 2 \\
\hline \multicolumn{3}{|l|}{ 利得接近志向尺度 } \\
\hline 1. どうやったら自分の目標や希望をかなえられるか，よく想像することがある。 & .68 & .02 \\
\hline 3.＼cjkstart私はたいてい，将来自分が成し遂げたいことに意識を集中している。 & .75 & -.08 \\
\hline 5. 私は, “自分の理想”を最優先し，自分の希望や願い・大志をかなえようと努力するタイプだと思う。 & .69 & -.24 \\
\hline 8.＼cjkstart私はたいてい，人生において良い成果をあげることに意識を集中している。 & .63 & .00 \\
\hline 9. 学校での私は，学業で自分の理想をかなえることを目指している。 & .55 & .14 \\
\hline 10. どうやったら良い成績がとれるかについて，よく考える。 & .44 & .32 \\
\hline 12.＼cjkstart将来どんな人間になりたいかについて，よく考える。 & .70 & .10 \\
\hline 15. こうなったらいいなと願っている事がかなう様子を，よく想像する。 & .35 & .04 \\
\hline \multicolumn{3}{|l|}{ 損失回避志向尺度 } \\
\hline 2. 私はたいてい, 悪い出来事を避けることに意識を集中している。 & -.08 & .50 \\
\hline 4. どうやったら失敗を防げるかについて, よく考える。 & .15 & .38 \\
\hline 6. 自分の責任や役割を果たせないのではないかと，よく心配になる。 & -.01 & .56 \\
\hline 7. 怖れている悪い出来事が自分にふりかかってくる様子を，よく想像する。 & -.09 & .67 \\
\hline 13． 目標とする成績をとれないのではないかと，よく心配になる。 & .10 & .71 \\
\hline 16.＼cjkstart学校での私は，学業での失敗を避けることを目指している。 & .12 & .52 \\
\hline 17. 自分が将来そうなってしまったら嫌だと思う自分像について，よく考えることがある。 & .12 & .46 \\
\hline \multirow[t]{4}{*}{ 18.＼cjkstart私にとっては，利益を得ることよりも，損失を避けることの方が大事だ。 } & -.26 & .53 \\
\hline & 3.19 & 2.59 \\
\hline & 19.96 & 16.20 \\
\hline & & .03 \\
\hline
\end{tabular}

の追求”は促進焦点の特徵である喜びの感情や熱望方 略とそれぞれ関連しているため, 利得接近志向尺度と 正相関したと考えられる $(r \mathrm{~s}=.39,25, p<.05)$ 。ま た, “回避ドライブ”はリスクを避ける傾向を表して おり，促進焦点の特徵の一つであるリスクをかえりみ ず挑戦する傾向（つまり熱望方略）とは対極の関係に あるため, 利得接近尺度と負相関したと思われる $(r=-.39, p<.01)$ 。このように促進焦点と関連のあ る測定指標と理論的に整合する相関関係が示されたこ とから, 利得接近志向尺度の併存的妥当性が確認され た。

“回避ドライブ”は苦痛やリスクを避けようとする 傾向を表しており，無損失を追求し損失を回避しょう とする損失回避志向と概念的に近似する。したがっ て，損失回避志向尺度と“回避ドライブ”の間に中程 度の正相関が示されたことは，この尺度の構成概念妥 当性の高さを表している $(r=.37, p<.01)$ 。“懸念 · 罰感受性” と“抑制性” は, 予防焦点の特徴である否 定的な基準への注目や熱望方略とそれぞれ関連してい るため, 損失回避志向と正相関したと考えられる $(r \mathrm{~s}=.47,32, p<.01)$ 。また, “報酬応答性”は目標達 成時の高揚感を表しており, 予防焦点の特徵の一つで ある成功に対して平静や安心などの静的感情を示す傾 向とは対極の関係にあるため, 損失回避尺度と負相関 したと思われる $(r \mathrm{~s}=-.35,-.40, p<.01)$ 。これらの
結果より, 損失回避志向尺度の併存的妥当性を確認す ることができた。以上のとおり, PPFS 邦訳版の信頼 性および妥当性が確認できたため, 研究 2 以降ではこ の尺度を制御的志向性の測定指標として用いる。

\section{研究 2}

\section{目 的}

研究 2 から研究 4 に共通する目的は, 利得接近志 向・損失回避志向と自己評価の相関関係について検討 することである。研究 2 では, 自己評価の感情価を表 す指標として自尊心を取り上げる。なぜなら，前述の とおり, 自己評価と接近志向・回避志向の関係性につ いて論じてきた先行研究の多くが自尊心という要因を 中心にして検討を進めてきたからである（Baumeister et al., 1989; Nadler, 1987; Roesch et al., 2005; Tessler \& Schwartz, 1972; Tice \& Masicampo, 2008)。これらの先 行研究の知見に対して, 本研究においても同じ変数 （すなわち自尊心）を用いて検討し，研究文脈の中で 本研究がどのように位置づけられるのかを確認するこ とが研究 2 の目的である。自尊心の測定法としては, 先行研究において最も頻繁に用いられているローゼン バーグ自尊心尺度（Rosenberg, 1965）を用いる。

“本研究の予測”に基づくと, 研究 2 における仮説 は以下のように導かれる。促進焦点のシステムは, 肯 
定的に自己評価するほど将来的な利益獲得の期待を高 めるため, 利得接近志向をより強く示すだろうと考え られる。したがって, 自尊心が高いほど利得接近志向 を強めるという関連性が予測される。一方, 予防焦点 のシステムは，否定的に自己評価するほど損失のリス クを高く見積もるため, 損失回避志向をより強く示す だろう。したがって, 自尊心が低いほど損失回避志向 を強めるという関連性が予測される。

\section{方 法}

調査参加者 大学生 50 名 (男 10 名, 女 40 名, 平 均年齢 $=20.98, S D=6.96 ）$ が参加した。

手続き 大学の授業時間中に質問紙調查を行った。 調査参加者は PPFS 邦訳版に 7 件法で回答した後, 邦 訳されたローゼンバーグ自尊心尺度（山本・松井・山 成，1982）に4 件法で回答した。

\section{結 果}

利得接近志向尺度, 損失回避志向尺度, 自尊心尺度 の合計得点を算出した。各尺度の信頼性は充分に高か った $(\alpha=.80, .75, .84)$ 。自尊心は利得接近志向と正 相関し, 損失回避志向と負相関した $(r \mathrm{~s}=.37,-.40$, $p<.01)$ 。また, 損失回避志向を統制した自尊心と利 得接近志向の偏相関 $(r=.27, p=.06)$ と, 利得接近 志向を統制した自尊心と損失回避志向の偏相関 $(r=$ $-.36, p=.01)$ についても同様の相関パターンが確認 され, 利得接近志向と損失回避志向がそれぞれ独自に 自尊心と関連していることが示された。

\section{考 察}

自尊心と接近回避傾向の関連についての研究文脈の 中で, 本研究は制御焦点理論に基づく利得接近志向と 損失回避志向の観点から接近回避傾向を定義した上 で，それに対応する測定指標を用いた初めての試みと して位置づけられる。結果として本研究の仮説どお り，自尊心が高いほど（すなわち自己評価が肯定的で あるほど）利得接近志向が強く, 自尊心が低いほど （すなわち自己評価が否定的であるほど）損失回避志 向が強いことが示された。

ただし，ローゼンバーグ自尊心尺度は一次元性を想 定した指標である7。この尺度を用いている限りは, 本研究で想定している自己評価の肯定性・否定性とい う概念を互いに独立した次元として測定することがで

7 ローゼンバーグ自尊心尺度を因子分析にかけると肯定的な 項目と否定的な項目がそれぞれ一つの因子を構成し 2 因子構造 になるという指摘がある（Marsh, 1996)。そこで本研究におい ても自尊心尺度 10 項目について因子分析を行ってみたところ, 固有值の減少パターン $(5.00,1.36,1.04,0.63,0.54 \cdots)$ から 1 因 子構造であることが示され, 先行研究の指摘するような 2 因子 構造にはならなかった。
きない。そこで研究 3 ・研究 4 では, 自己評価の感情 価の測定指標として各概念を独立次元として測定しう る手続きを用いて検討する。

\section{研 究 3}

\section{目 的}

研究 3 の目的は, 研究 2 から引き続き, 利得接近志 向・損失回避志向と自己評価の肯定性・否定性の相関 関係について検討することである。ただし, 研究 3 で は自己評価の肯定性と否定性の測定法を改善し, 肯定 的あるいは否定的な性格特性語について自分にどのく らいあてはまると思うかを調查参加者に評定させる。 もし肯定的な特性語に対して“あてはまる”と回答す る度合が強ければ自己評価の肯定性が高いということ を表し，否定的な特性語に対して“あてはまる”と回 答する度合が強ければ自己評価の否定性が高いことを 意味する。このようにして測定された自己評価の肯定 性と否定性は必ずしも負の相関を示すとは限らず, 理 論的に独立した関係性にあると考えられる。

\section{方 法}

調査項目の選定 自己評価の測定に用いる性格特性 語の選定のために, 予備調査を行った。まず, 性格特 性語を収集した先行研究（青木，1971）を参考に, 日 常的な使用頻度が高いと思われる語を実験者が判断し て選び 140 語を予備調査の対象とした。24名の大学 生および大学院生が予備調查に参加し, 各性格特性語 について自分にあてはまるかあてはまらないかを 2 択 で評定した後, 各単語がどのくらい良い性質あるいは 悪い性質を表していると思うかを 5 件法で評定した。 この結果をもとに, 反応の偏りの少ない項目を選ぶた めに, 自分にあてはまるという回答割合が全体の $33 \%$ 以上 $67 \%$ 未満であった性格特性語を選出した。 これらの中から望ましさ評定の平均值が 4.0 以上であ つた 46 語を肯定的特性語の候補, 2.0 未満であった 33 語を否定的特性語の候補とした。これらの候補の 中から, 肯定的特性語と否定的特性語の各平均文字数 がほぼ均等になるように 20 語ずつ選出し, 計 40 語を 最終的な性格特性語リストとして決定した 8 。

調查参加者 専門学校生 129 名（男 2 名, 女 126 名, 不明 1 名; 平均年齢 $=18.77, S D=1.01 ）$ が参加し た。

手続き 授業時間中に質問紙調查を行った。まず, 予備調査で選定された性格特性語 40 語がランダムに

\footnotetext{
8 選出された特性語の例を挙げると, 肯定的特性語は“親切 な”“丁寧な”“自発的な”“気立てのよい”など，否定的特性語 は“いい加減な”“自己中心的”“しつこい”“飽きっぽい”など であった。
} 
並べられたリストについて，自分にどのくらいあては まるかを“1．全くあてはまらない”から“7．非常に あてはまる”までの 7 件法で評定した。続いて, PPFS 邦訳版に 7 件法で回答した。

\section{結 果}

PPFS 邦訳版の利得接近志向 8 項目と損失回避志向 8 項目の合計得点をそれぞれ算出した。自己評価の肯 定性の得点として肯定的な性格特性 20 項目の合計得 点を, 自己評価の否定性の得点として否定的な性格特 性 20 項目の合計得点を算出した。各尺度の信頼性は 充分に高かった $(\alpha=.84, .81, .85, .84)$ 。

自己評価の肯定性は利得接近志向と正相関したが, 損失回避志向とは相関が見られなかった $(r=.47$, $p<.01 ; r=-.01, n s)$ 。また, 自己評価の否定性は損失回 避志向と正相関し，利得接近志向とは弱い負相関の有 意傾向が示された $(r=.23, p<.05 ; r=-.16, p<.10)$ 。

自己評価の肯定性と否定性の間には中程度の負相関 が見られ，利得接近志向と損失回避志向の間には中程 度の正相関が見られた $(r \mathrm{~s}=-.39, .33, p<.05)$ 。これ らの指標間の関連を統計的に統制して各指標の独自の 効果を検定するために, 自己評価の肯定性・否定性と 利得接近志向・損失回避志向の関連について, それ以 外の変数を統制した偏相関を算出した（たとえば，自 己評価の肯定性と利得接近志向の偏相関を計算すると きには，自己評価の否定性および損失回避志向を統制 した)。結果, 自己評価の肯定性は利得接近志向と正 相関し, 自己評価の否定性は損失回避志向と正相関し た $(r \mathrm{~s}=.45, .25, p<.01)$ 。自己評価の肯定性と損失回 避志向, 自己評価の否定性と利得接近志向の間の偏相 関はいずれも有意ではなかった $(r \mathrm{~s}=-.08,-.11, n s)$ 。

\section{考 察}

本研究の予測どおり，自己評価の肯定性が高いほど 利得接近志向が強く, 自己評価の否定性が高いほど損 失回避志向が強いことが明らかになった。また, 自己 評価の肯定性は損失回避志向と無関連であり, 自己評 価の否定性は利得接近志向と無関連であることも確認 された。これらの結果は, 自己評価の肯定性・否定性 をそれぞれ独立次元として概念化および測定すること の重要性および意義を示唆している。

ただし, 研究 3 で用いた特性語リストがもともと利 得接近・損失回避志向と交絡していたのではないかと いう批判も考えうる9。特に, 外向性などの接近的志

9 研究 3 で用いられた特性語リストには, 利得接近志向と関 連していると考えられるものとして“意欲的な”“活動的な”

“積極的な” “勤勉な” の 4 語, 損失回避志向と関連していると 考えられるものとして“きちょうめんな”“びくびくした”の 2 語が含まれていた。
向と関連の強い性格特性次元や, 消極性などの回避的 志向と関連の強い性格特性次元に偏った項目ばかりが 特性語リストに含まれていた場合, 交絡の問題が発生 する。性格特性語リストに対して自己評定させる方法 を用いている限り, この交絡の恐れは常につきまと う。そこで研究 4 ではこの問題に対処するための手続 き的改善を加える。

\section{研 究 4}

研究 4 の目的は, 研究 2,3 と同様, 制御的志向性 と自己評価の感情価の相関関係について検討すること である。研究 4 では自己評価測定について手続き的改 善が加えられ, 調查参加者が自分自身について思い浮 かべるイメージ内容の肯定性㧍よび否定性を分析する 手法を用いる。具体的には, “私は”から始まる20の 文章を作成させる二十答法と呼ばれる方法を用いる。

この手法はアイデンティティや作動的自己概念の内容 を測る指標であるが, 自尊心の測定指標として用いる こともできる。たとえば Rentsch \& Heffner (1992) の研究では, 二十答法に回答させた後, 記述した各文 章について調查参加者本人がどのくらい肯定的あるい は否定的に感じているかを評定させ，その合計点を算 出した。Rentsch \& Heffnerは, このようにして算出 した得点は自分に対する評価的な感情や認知を反映し ているため, 自己評価の高低を表す指標になると主張 し, 自尊心尺度（Rosenberg, 1965）との併存的妥当 性も確認している。そこで研究 4 では, 上記の手続き を応用して自己評価の感情価を測定することにした。 具体的には, 二十答法に回答後, 各記述の中で肯定的 な記述と思われるもの（自分の長所だと思うもの）と 否定的な記述と思われるもの（自分の短所だと思うも の）の個数を調查参加者本人にカウントさせる。この とき, どちらともいえないものはカウントに含めなく てよいと教示する。このような手続きによって, 自己 評価の肯定性と否定性を理論的に独立した次元として 測定可能になる。

\section{方 法}

調査参加者 大学生 39 名 (男 32 名, 女 7 名, 平均 年齢 $=20.03, S D=1.09 ）$ が参加した。

手続き 大学の授業時間中に 1 週間間隔で 2 度にわ たる質問紙調查が行われた。まず 1 度目の調查とし て, 回答者はPPFS 邦訳版の 16 項目について“1. 全 くあてはまらない”から“7. 非常にあてはまる”ま での 7 件法で評定した。その 1 週間後に 2 度目の調査 が行われた。調査用紙には“あなたは誰ですか？どん な人物ですか？とたずねられたら，あなたはどのよう に答えますか？あなたの答えを 20 通り書いてくださ い。思いつくままに，上から順番に記入してくださ い。という教示に続いて, 回答欄が 20 項目設けてあ 
つた。全員が記入し終わったのを確認してから，20 項目のうち長所だと思う記述数, 短所だと思う記述数 を調査参加者自身にカウントするように求め, 調査用 紙に記入させた。どちらともいえないものはカウント に含めなくてよいと教示した。

\section{結果と考察}

PPFS 邦訳版の利得接近志向 8 項目の合計得点と, 損失回避志向 8 項目の合計得点を算出した。各尺度の 信頼性は充分に高かった $(\alpha=.82, .81)$ 。自己評価の 肯定性・否定性の得点としては回答者が報告した二十 答法回答に含まれる長所・短所の数をそれぞれ用い た。

結果, 自己評価の肯定性は利得接近志向や損失回避 志向と有意な相関が見られなかった $(r \mathrm{~s}=.28,-.16$, $n s)$ 。また，自己評価の否定性は損失回避志向と正相 関し, 利得接近志向とは相関しなかった $(r=.33$, $p<.05 ; r=-.19, n s)$ 。次に, 自己評価の肯定性・否定 性と利得接近志向 ·損失回避志向の関連について, そ れ以外の変数を統制した偏相関を算出した（たとえ ば, 自己評価の肯定性と利得接近志向の偏相関を計算 するときには，自己評価の否定性および損失回避志向 を統制した)。結果, 自己評価の肯定性は利得接近志 向と有意傾向の正相関が見られたが，損失回避傾向と は無相関であった $(r=.31, p=.07 ; r=-.26, n s)$ 。自己 評価の否定性は損失回避志向と有意に正相関したが, 利得接近志向とは無相関であった $(r=.33, p<.05 ; r=$ $-.12, n s)$ 。したがって, 肯定的な記述数は利得接近志 向の得点と正相関しており，その関係性は否定的な記 述数とは共通しない独自の分散から生じていることが 示された。一方, 否定的な記述数は損失回避志向の得 点と正相関し，その関係性は自己評価の肯定性とは共 通しない独自の分散から生じていることが示された。

二十答法の記述内容に性格特性語の含まれていた割 合は, 長所のうち $13 \%$, 短所のうち $15 \%$ であった。 このように記述内容に含まれる性格特性語の割合が小 さかったことから, 研究 3 の考察で述べたような性格 特性語と利得接近志向・損失回避志向の交絡によって 相関が生じたという代替説明は排除されたと考えられ る。また，二十答法の前にPPFS に回答したことが結 果に影響を及ぼしている可能性もあるが，一週間とい う遅延期間を置いていることからその影響はさほど大 きなものではないと思われ，本研究の結果を全て説明 するものではないと考えられる。

以上をまとめると，自己評価が肯定的であるほど利 得接近志向が強く，自己評価が否定的であるほど損失 回避志向が強いという本研究の予測を支持する結果が 得られた。また, 研究 3 と同様, 自己評価の肯定性は 利得接近志向のみと相関し損失回避志向とは相関しな いこと，そして自己評価の否定性は損失回避志向のみ
と相関し利得接近志向とは相関しないことが明らかに なった。

\section{総合考察}

研究 1 では利得接近・損失回避志向の測定尺度を開 発した。研究 2，3，4 では，自己評価の肯定性が高い 人ほど利得接近志向が強く, 自己評価の否定性が高い 人ほど損失回避志向が強いという相関関係が示され, 本研究の予測が支持された。研究 2，3，4 は小規模な 調査であり調査参加者の男女比の偏りも見られるが,

一貫した結果が得られたことは現象の頑健性を示唆し ている。今後，規模を拡大した調查などによる検証を 重ね, この現象が安定して示されることを確認してい くことが重要な課題である。

本研究の意義の一つは, 促進焦点と予防焦点という 二つの自己制御システムに扔いて, 自己評価の感情価 が異なる影響をもたらすことを指摘した点にある。促 進焦点の場合は自己評価の肯定性に反応し，それが高 いほど将来的な成功や利益への期待を高めて利得接近 志向をより強く示す。一方, 予防焦点の場合は自己評 価の否定性に反応し，それが高いほど将来的な失敗や 損害のリスクに脅威を感じて損失回避志向をより強く 示す。すなわち，自己評価と自己制御の間には密接な 関係性があり, 自己評価の内容に応じて自己制御シス テムは柔軟に目標達成行動をコントロールしているこ とが推察される。人間の自己評価は時々刻々と変動す る。このような自己評価の変動性は, 状況に応じた柔 軟な行動調整を生じさせ, 結果として効率的な目標達 成のために役立っている可能性も考えられる。ただ し, 本研究は調査による相関関倸の検証に留まってい るため, 要因間の因果関係については推測の域を出な い。この問題を解明するには自己評価を操作するなど の実験的検証が必要であり, 今後の課題として挙げら れる。

本研究のもう一つの意義は, 自己評価の肯定性・否 定性を弁別し，それぞれがもたらす独自の効果を検証 したことである。従来の自尊心研究や自己評価研究で は，自己評価を一次元的概念として取り扱ってきた。 しかし本研究の結果は, 一次元的概念を想定するだけ では捉えきれない心理現象が存在することを示唆して いる。本研究のように，自己評価の二次元それぞれ が, 異なる状況下で異なる心理的影響をもたらすこと を想定することによって, 従来の自尊心研究を超えた 研究可能性が広がり, 新たな知見が得られることが期 待される。

たいていの個人は促進焦点と予防焦点の両方のシス テムを併せ持っており，状況に応じてそれぞれを活性 化させるという（Higgins, 1997, 1998）。したがって, いずれの焦点が活性化しているかによって, 自己評価 が肯定的であるほど利得接近的に動機づけられるとき 
もあれば，逆に自己評価が否定的であるほど損失回避 的な動機づけが強まることもあるだろうと予測され る。この予測に関して本研究では検証を行わなかった が，今後研究を進めることにより，自己評価と自己制 御の連携的関係性をより詳細に解明するために役立つ だろう。

\section{引用文献}

青木 孝悦 (1971). 性格表現用語の心理-辞典的研究 — 455 語の選択, 分類および望ましさの評定 —— 心理学研究, 42, 1-13.

(Aoki, T. (1971). A psycho-lexical study of personality trait words: Selection, classification and desirability ratings of 455 words. Japanese Journal of Psychology, 42, 1-13.)

Baumeister, R.F., Tice, D. M., \& Hutton, D. G. (1989). Self-presentational motivations and personality-differences in self-esteem. Journal of Personality, 57, 547-579.

Cacioppo, J. T., \& Berntson, G. G. (1994). Relationship between attitudes and evaluative space: A critical-review, with emphasis on the separability of positive and negative substrates. Psychological Bulletin, 115, 401-423.

Carver, C. S., \& Scheier, M. F. (1982). Control theory: A useful conceptual framework for personalitysocial, clinical, and health psychology. Psychological Bulletin, 92, 111-135.

Higgins, E. T. (1997). Beyond pleasure and pain. American Psychologist, 52, 1280-1300.

Higgins, E. T. (1998). Promotion and prevention: Regulatory focus as a motivational principle. In M. P. Zanna (Ed.), Advances in experimental social psychology. Vol. 30. New York: Academic Press. pp. 1-46.

Lockwood, P., Jordan, C. H., \& Kunda, Z. (2002). Motivation by positive or negative role models: Regulatory focus determines who will best inspire us. Journal of Personality and Social Psychology, 83, 854-864.

Marsh, H. W. (1996). Positive and negative global selfesteem: A substantively meaningful distinction or artifactors? Journal of Personality and Social Psychology, 70, 810-819.

Nadler, A. (1987). Determinants of help seeking behavior: The effects of helpers similarity, task centrality and recipients self-esteem. European Journal of Social Psychology, 17, 57-67.

Rentsch, J. R., \& Heffner, T. S. (1992). Measuring selfesteem: Validation of a new scoring technique for "Who am I" responses. Educational and Psychological Measurement, 52, 641-651.

Roesch, S. C., Adams, L., Hines, A., Palmores, A., Vyas, P., Tran, C., Pekin, S., \& Vaughn, A. A. (2005). Coping with prostate cancer: A meta-analytic review. Journal of Behavioral Medicine, 28, 281-293.

Rosenberg, M. (1965). Society and the adolescent selfimage. Princeton, NJ: Princeton University Press.

Summerville, A., \& Roese, N. J. (2008). Self-report measures of individual differences in regulatory focus: A cautionary note. Journal of Research in Personality, 42, 247-254.

Tessler, R. C., \& Schwartz, S. H. (1972). Help-seeking, self-esteem, and achievement motivation: An attributional motivation. Journal of Personality and Social Psychology, 21, 318-326.

Tice, D. M., \& Masicampo, E. J. (2008) . Approach and avoidance motivations in the self-concept and selfesteem. In A. Elliot (Ed.), Handbook of approach and avoidance motivation. Mahwah, NJ: Erlbaum. pp. 505-519.

山本 真理子 ・松井 豊・山成 由紀子 (1982). 認知さ れた自己の諸側面の構造 教育心理学研究, 30 , 64-68.

(Yamamoto, M., Matsui, Y., \& Yamanari, Y. (1982). The structure of perceived aspects of self. Japanese Journal of Educational Psychology, 30, 6468.)

安田朝子・佐藤 徳 (2002). 行動抑制システム・行 動接近システム尺度の作成ならびにその信頼性と 妥当性の検討 心理学研究, 73, 234-242.

(Yasuda, A., \& Sato, A. (2002). Development of the behavioral inhibition system/behavioral approach system scales. Japanese Journal of Psycho$\log y, \mathbf{7 3}, 234-242$. )

- 2010. 12. 1 受稿, 2011. 7.2 受理—— 